suggest that general practitioners are more capable of discriminating mild disease from normality than they admit to in a referral letter.

Only one third of the children had an investigation. This is contrary to suggestions that investigation of every heart murmur is mandatory. In fact, the diagnosis of quiet asymptomatic murmurs is unlikely to be greatly helped by chest radiography or electrocardiography, and echocardiography without Doppler studies is not sensitive in discriminating mild disease from normal anatomy. ${ }^{2}$

1 Newburger JW, Rosenthal A, Williams RG, Fellows K, Miettinen OS. Non invasive tests in the initial evaluation of heart murmurs in children. NEngl f Med 1983;308:61-4

2 Wilson $\mathrm{N}$. The use of doppler echocardiography in congenital heart disease. In David TJ, ed. Recent advances in paediatrics. Vol 8. Edinburgh: Churchill Livingstone, 1986:87-101.

(Accepted 21 September 1992)

\title{
Driving and diabetes mellitus
}

\section{J P Saunders}

\section{Academic Unit of Public \\ Health Medicine, \\ University of Leeds, Leeds \\ LS2 9LN \\ C J P Saunders, registrar}

Correspondence to: Health Medicine, York Health Authority, York YO3 $7 \mathrm{BY}$

$B M 7$ 1992;305:1265 Department of Public

People with diabetes mellitus are obliged under the Road Traffic Act 1974 to report their diabetes to the licensing authority and, if eligible, are issued a driving licence valid for up to three years. Although one study in Oklahoma found the accident rate for male diabetic drivers to be slightly higher than that for the general population, ${ }^{1}$ another in Western Australia found no overall difference in the rates of admission to hospital after road accidents between those with diabetes and the general population. ${ }^{2}$ Studies in Edinburgh in the early 1980s showed that just over half of people with insulin dependent diabetes and about a quarter of people with non-insulin dependent diabetes reported having informed the licensing authority or their motor insurers of their diabetes. ${ }^{34}$ I attempted to find whether the situation had changed since 1982 .

\section{Subjects, methods, and results}

In autumn 1991 I sent a standardised postal questionnaire to the total known diabetic population of four randomly selected general practices in one health district in Yorkshire (312 people). Among other questions the people were asked whether they drove a motor vehicle, whether they had informed the Driver and Vehicle Licensing Agency or their motor insurers of their diabetes, and the renewal date of their driving licence. A total of 287 completed questionnaires $(92 \%)$ were returned by 155 men and 132 women (median age 67 (interquartile range 57-77)), of whom 70 reported receiving insulin. The respondents' age, sex, insulin status, and duration of diabetes were not significantly different from those found in a previous survey. ${ }^{5}$

Drivers who reported having notified licensing authority and motor insurers of diabetes by age group and renewal date of licence. Figures are numbers (percentages)

\begin{tabular}{|c|c|c|c|c|c|}
\hline \multirow[b]{3}{*}{$\begin{array}{l}\text { Whether notification } \\
\text { given }\end{array}$} & \multicolumn{3}{|c|}{ Age $<67(n=92)$} & \multirow[b]{3}{*}{$\begin{array}{c}\text { Age } \geqslant 67 \\
(\mathrm{n}=39)\end{array}$} & \multirow[b]{3}{*}{$\begin{array}{l}\text { All ages } \\
(n=131)\end{array}$} \\
\hline & \multicolumn{2}{|c|}{ Renewal date of licence } & \multirow[b]{2}{*}{ All drivers ${ }^{\star}$} & & \\
\hline & $\begin{array}{c}<3 \text { Years } \\
(n=51)\end{array}$ & $\begin{array}{c}>3 \text { Years } \\
(\mathrm{n}=30)\end{array}$ & & & \\
\hline \multicolumn{6}{|l|}{ To licensing authority: } \\
\hline Yes & $48(94)$ & $13(43)$ & $68(74)$ & $32(82)$ & $100(76)$ \\
\hline No & $3(6)$ & $15(50)$ & $22(24)$ & $6(15)$ & $28(21)$ \\
\hline \multirow{2}{*}{\multicolumn{6}{|c|}{ To motor insurers: }} \\
\hline & & & & & \\
\hline Yes & $46(90)$ & $17(57)$ & $69(75)$ & $32(82)$ & $101(77)$ \\
\hline No & $3(6)$ & $12(40)$ & $20(22)$ & $6(15)$ & $26(20)$ \\
\hline Don't know & $2(4)$ & $1(3)$ & $3(3)$ & $1(3)$ & $4(3)$ \\
\hline
\end{tabular}

*Includes 11 drivers aged $<67$ who did not give renewal date of licence.
Of the 131 respondents who reported driving, 100 claimed to have informed the licensing authority of their diabetes (table). Of the 92 drivers aged under 67, 11 did not give renewal dates for their licences but answered all the other questions; only 51 of the remaining 81 gave renewal dates for their licences that were within three years. Drivers receiving insulin were significantly more likely to report having informed the licensing authority of their diabetes than drivers not receiving insulin $\left(\chi^{2}=5 \cdot 37, p=0.0205\right)$. One hundred and one drivers reported having informed their motor insurers of their diabetes. Again, drivers receiving insulin were significantly more likely to report having informed their insurers than other diabetic drivers $\left(\chi^{2}=9 \cdot 14, p=0 \cdot 0025\right)$.

\section{Comment}

I have no reason to believe that the people I surveyed differed greatly from the general diabetic population of the United Kingdom. I found that about a fifth of all diabetic drivers reported not informing the Driver and Vehicle Licensing Agency or their motor insurers of their diabetes. Of the drivers aged below 67 who claimed to have informed the licensing authority, a fifth gave renewal dates for their licences that were more than three years in the future and hence incompatible with them having done so. The reasons why many diabetic drivers fail to notify the licensing authority or their motor insurers are unclear, but ignorance of the legal requirements and fear of having their driving licence taken away may be possible explanations. Evidence supporting legal discrimination against drivers with diabetes mellitus is unclear; this possibly explains the apparent lack of official concern about underreporting of diabetes mellitus by nonvocational drivers.

Better evidence is required to determine what additional risk diabetic drivers pose compared with other drivers. Meanwhile those caring for people with diabetes should ensure that diabetic drivers are aware of the possible consequences of not informing the licensing authority and motor insurers of their diabetes.

1 Davis TG, Wehling EH, Carpenter RE. Oklahoma's medically restricted drivers-a study of selected medical conditions. Oklahoma State Medical Association fournal 1973;66:322-7.

2 DeKlerk NH, Armstrong BK. Admission to hospital for road trauma in patients with diabetes mellitus. I Epidemiol Community Health 1983;37:232-7.

3 Frier BM, Steel JM, Matthews DM, Duncan LJP. Driving and insulindependent diabetes. Lancet 1980;i:1232-4.

4 Steel JM, Young RJ, Frier BM, Duncan LJP. Driving and insulin-independen diabetes. Lancet 1981;ii:354-6.

5 Williams DDR, Munroe C, Hospedales CJ, Greenwood RH. A three-year evaluation of the quality of diabetes care in the Norwich community care scheme. Diabetic Med 1990;7:74-9. 